\title{
ПРОФІЛАКТИКА ТУБЕРКУЛЬОЗУ
}

\author{
Т. Я. Тимощук \\ Комунальний вищий навчальний заклад \\ "Бердичівський медичний коледж" Житомирської обласної ради
}

У статті висвітлено основні аспекти профілактики туберкульозу: соціальний, санітарний і специфічний. Профілактика туберкульозу посідає важливе місце в комплексі заходів, спрямованих на боротьбу з туберкульозом.

\section{PREVENTION OF THE TUBERCULOSIS}

\author{
T. Ya. Tymoshchuk \\ Municipal Higher Educational Establishment \\ "Berdychiv Medical College» of Zhytomyr Regional Council
}

This article contains the main aspects of the TB prevention: social, sanitary and specific. The prevention of tuberculosis plays an important role in the complex of measures, directed on the struggle with tuberculosis.

Встүп. Розвиток світовоїфтизіатричноїнаукидав змогу розробити низку заходів і програм контролю за туберкульозом. Своєчасне виявлення туберкульозу є вирішальним фактором для ефективного лікування та попередження поширення його серед людей. Чим раніше виявлено захворювання, тим більше шансів на повне одужання при умові ефективного лікування. Через те профілактику туберкульозу потрібно здійснювати комплексно, у тому числі разом з іншими протитуберкульозними заходами [1, 2].

Основна частина. Профілактика туберкульозу - це комплекс заходів, спрямованих на попередження інфікованості й виникнення захворювання. Ними передбачено ліквідацію джерела, шляхів поширення та збільшення опірності організму до інфекції. Профілактика туберкульозу $\epsilon$ пріоритетною в системі державної охорони здоров'я і проводиться в таких напрямках $[3,4]$ :

- заходи серед усього населення України з метою створення надійного прошарку людей, опірного до туберкульозу. Це досягається шляхом

(C) Т. Я. Тимощук, 2014 зростання соціально-економічного та санітарногігієнічного рівня життя, підвищенням санітарної грамотності населення і щепленням вакциною БЦЖ;

- визначення груп ризику і ї диспансеризація 3 метою попередження інфікування та захворювання;

- оздоровлення вогнищ туберкульозної інфекції, дезінфекція, ізоляція бактеріовиділювачів і лікування всіх хворих на активний туберкульоз;

- ефективний ветеринарний нагляд за станом захворюваності на туберкульоз свійських тварин в громадському та індивідуальному сільськогосподарському секторі.

Усі зазначені профілактичні заходи взаємопов'язані й повинні здійснюватися з урахуванням поширеності түберкульозної інфекції [5].

Профрілактика туберкульозу включає:

- санітарну профрілактику;

- соціальну профрілактику;

- специфічну профілактику;

- хіміопрофілактику.

Метою санітарної профілактики $є$ попередження інфікування МБТ здорових людей і ство- 
рення умов, при яких їх контакт із джерелом туберкульозної інфекції в побуті й на роботі стає найменш небезпечним. Санітарна профілактика спрямована насамперед на джерело бактеріовиділення та шляхи передачі збудника туберкульозу. Важливою складовою частиною санітарної профрілактики $є$ проведення соціальних, протиепідемічних та лікувальних заходів у вогнищі туберкульозної інфекції (в сім'ї й оселі хворого на туберкульоз, який виділяє МБТ) $[5,6]$.

Критеріями епідемічної безпеки вогнища туберкульозної інфекціі є:

- масивне й постійне виділення хворим МБТ;

- сімейно-побутові умови проживання хворого;

- поведінка хворого;

- загальна культурай санітарна грамотність хворого й оточуючих його людей.

На основі цих критеріїв вогнища туберкульозної інфекції за ступенем епідемічної безпеки розподіляють на три групи. Відповідно до групи визначають об'єм і характер профілактичних заходів у вогнищі $[4,7]$.

І група - найбільш несприятливі вогнища: 1) хворий з наявним бактеріовиділенням, який мешкає в комунальній квартирі або гуртожитку; 2) у родині хворого є діти, підлітки, вагітні; 3) родина має погані умови життя, хворий та оточуючі його не дотримуються гігієнічних правил поведінки.

II група - відносно несприятливі вогнища: 1) у хворого мізерне бактеріовиділення, стійкий туберкульозний процес; 2) у родині хворого дорослі люди, відсутні обтяжуючі чинники; 3) хворий $є$ умовним бактеріовиділювачем, але в його родині є діти й в наявності обтяжуючі чинники.

III група - потенційно небезпечні вогнища: 1) хворий умовний бактеріовиділювач (бактеріовиділення припинилось, але ще не минуло 2 років); 2) в родині хворого лише дорослі; 3) хворий і оточуючі його виконують усі необхідні санітарногігієнічні заходи профрілактики туберкульозу.

В осередку туберкульозної інфекції потрібно розповідати хворому і членам його сім'ї про шляхи зараження туберкульозом і методи його попередження, навчити правил гігієни, методики поточної дезінфекціі. При кашлі та чханні хворий повинен прикривати рот і ніс новим платком, відвертатися при цьому від оточуючих. Необхідно мати дві кишенькові плювальниці. Вона повинна бути заповнена на $2 / 35$ \% розчином хлораміну. Після спорожнення її необхідно прокип'ятити в 2 \% розчині гідрокарбонату натрію. Посуд хво- рого потрібно зберігати окремо і кип'ятити після його використання протягом 15 хв. Необхідно також кип'ятити натільну і постільну білизну хворого. Прибирання приміщень проводять вологим способом. Підлогу і меблі кожного дня протирають $5 \%$ розчином хлораміну, хворому виділяють окрему кімнату або відділяють їі ширмою. Медпрацівники, які контактують з хворими, повинні ретельно мити руки з милом, одягати халати, маски, рукавички. Особам, які проживають разом із хворим, пояснюють важливість регулярних обстежень у тубдиспансері, при необхідності - профрілактичного лікування. Всі люди, які були у вогнищі туберкульозу, повинні бути на диспансерному обліку протягом 2 років $[3,5]$.

Для активного виявлення хворих на туберкульоз на ранніх стадіях проводять флюорографічне обстеження населення. Флюорографія найбільш надійний метод виявлення приховано перебігаючого туберкульозу та інших захворювань легень. Обов'язкове флюорографічне обстеження проводять населенню старше 15 років не менше 1 разу на 2 роки. Кожна свідома людина повинна розцінювати флюорографічне обстеження як свій громадянський обов'язок $[1,4]$.

Важливим методом виявлення туберкульозу $\epsilon$ обстеження харкотиння на наявність мікобактерій в осіб, які тривалий час кашляють [1, 5].

У профілактиці туберкульозу відіграють важливе значення загальнооздоровчі заходи, спрямовані на підвищення імунної реактивності організму. Провідна роль належить організації правильного режиму дня і харчування, проведенню загартовувальних процедур, заняттю фізкультурою і спортом, веденню здорового способу життя $[2,5]$.

Провідним розділом санітарної профрілактики $\epsilon$ попередження зараження людини від хворих тварин. Захворювання на туберкульоз зустрічається у 55 видів ссавців і 80 видів птахів. Проте епідемічну небезпеку для людини становить, здебільшого, велика рогата худоба, значно менше кози, вівці, свині, верблюди, кішки, собаки, кури. Особливе значення мають корови, які можуть інфікуватися не лише бичачим, але й людським типом МБТ. Отже, можливе зараження людини від худоби і навпаки - корів від людини. Людина може заразитися через молоко, М'ясо, субпродукти від хворих тварин, а також безпосередньо при догляді за ними. За виявлення і попередження туберкульозу в тварин відповідає ветеринарна служ- 
ба. Здійснюється систематичне обстеження тварин за допомогою туберкулінодіагностики, заражена худоба знищується. Для ранньої діагностики туберкульозу працівники ферм, де виявлена заражена туберкульозом худоба, повинніщорічно проходити флюорографічне обстеження. Щоб попередити інфікування здорових корів, до роботи на фермах не допускаються люди, хворі на туберкульоз.

Отже, метою санітарної профілактики $є$ запобігання інфікуванню здорових людей шляхом проведення санітарно-освітніх, протиепідемічних і лікувальних заходів у осередках туберкульозної інфекції.

Соціальна профілактика включає державні заходи, спрямовані на підвищення життєвого рівня населення, захист довкілля, розвиток фізкультури і спорту, санаторної мережі, будинків відпочинку. Забезпечення житлом, задовільними умовами праці, повноцінним харчуванням - важливі умови зміцнення здоров'я народу і підвищення опірності до різних захворювань, в тому числі до туберкульозу. Для профрілактики розповсюдження туберкульозу, попередження захворювання здорових членів сім'ї важливе значення має право хворих із туберкульозом, що виділяють МБТ, на позачергове отримання житла, в якому хворому забезпечується окрема кімната. Таким чином, туберкульоз як соціальна хвороба здебільшого залежить від соціальних умов, поліпшення яких сприятиме ліквідації епідемії туберкульозу, а в подальшому й зниженню епідеміологічних показників цього захворювання.

Найдієвішим методом специфічної профілактики туберкульозу $є$ вакцинація й ревакцинація вакциною БЦЖ, або специфічна імунопрофілактика.

В Україні для активної специфічної профрілактики туберкульозу застосовують вакцину туберкульозну (БЦЖ) суху для внутрішньошкірного введення. Це живі мікобактерії туберкульозу вакцинного штаму БЦЖ-1, ліофільно висушені в 1,5\% розчині натрію глютамінату. Вакцинування БЦЖ проводиться всім здоровим доношеним новонародженим дітям на 3-5 день життя, а також дітям віком 7 та 14 років, які мають негативну туберкулінову пробу. Для своєчасного виявлення інфрікованих мікобактеріями та хворих на туберкульоз дітей віком до 14 років їм щороку проводять пробу Манту з 2 ТО туберкуліну. Позитивна проба Манту ще не означає, що дитина хвора на туберкульоз. Проте це $\epsilon$ підставою для диспансерного спостереження у дитячого фтизіатра. Ефективність протитуберкульозних щеплень БЦЖ проявляється у тому, що серед вакцинованих і ревакцинованих дітей і підлітків захворюваність на түберкульоз нижча, ніж серед невакцинованих. На жаль, багато наших громадян відмовляються проводити пробу Манту своїм дітям. На тлі загрозливої епідемічної ситуації щодо захворюваності на туберкульоз у нашій країні таке рішення $\epsilon$, $M^{\prime}$ яко кажучи, нерозважливим. Адже туберкульоз на початковій стадії добре піддається лікуванню, у випадку ж задавнення хвороби може статися непоправне. Підступність туберкульозу в тому, що часто він перебігає безсимптомно, ніяк не проявляючи себе. Тому проба Манту на сьогодні - єдиний спосіб оцінити, у яких "стосунках» перебуває імунітет дитини з туберкульозною бактерією.

Другим методом специяічної профілактики туберкульозу є хіміопрофрілактика - застосування протитуберкульозних препаратів із метою попередження туберкульозу в осіб, які зазнають найбільшої небезпеки зараження та захворювання на туберкульоз. Виділяють первинну та вторинну хіміопрофрілактику.

Первинна профрілактика проводиться для запобігання захворюванню на туберкульоз неінфікованих осіб, які не реагують на туберкулін, але перебували в контакті з хворими на туберкульоз і виділяють МБТ.

Вторинна профілактика проводиться інфокованим особам, які позитивно реагують на туберкулін і не мають клініко-рентгенологічних проявів туберкульозу.

Хіміопрофілактику протитуберкульозними препаратами проводять для попередження захворювання на туберкульоз таким групам населення:

- особам, якіперебувають в постійному контакті 3 хворими на туберкульоз із бактеріовиділенням;

- особам, які мають неактивні туберкульозні зміни, при наявностінесприятливих чинників (гострі захворювання, операціі, травми, лікування іншого захворювання, що супроводжується прийманням кортикостероїдів та ін.), які можуть визвати реактивацію туберкульозу;

- особам, які раніше лікувались від туберкульозу, з великими залишковими змінами в легенях $i$ перебувають в небезпечному оточенні;

- особам, у яких визначено віраж туберкуліновихреакцій;

- ВІЛ-інфікованим з гіперергічними реакціями на туберкулін. 
Серед осіб, які отримували хіміопрофрілактику, захворюваність у 2-5 разів нижча, порівняно з відповідними групами, які ї̈ не отримували.

Висновки. 1. Серед населення необхідно пропагувати здоровий спосіб життя, роз'яснювати шкідливість алкоголю, куріння, важливість щеплень БЦЖ для попередження туберкульозу, флюорографічних обстежень і туберкулінодіагностики як методів раннього виявлення захворювання. Разом з тим необхідно пояснити, що при появі навіть мінімальних симптомів хвороби потрібно звертатися за медичною допомогою, тому що лише при ранній діагностиці захворювання виліковується повністю.

2. В осередку туберкульозної інфекції необхідно розповідати хворому і членам його сім'ї про шляхи зараження туберкульозом і методи його попередження, навчити правил гігієни, методики поточної дезінфекції. Особам, які проживають разом із хворим, пояснюють важливість регулярних обстежень у тубдиспансері, при необхідності - профрілактичного лікування.

3. Тваринникам, які працюють у господарствах, де $\epsilon$ заражена туберкульозом худоба, потрібно розповідати про зв'язок між туберкульозом людей і тварин, способи попередження зараження, необхідність регулярних флюорографічних обстежень, хіміопрофрілактики.

4. Піклуйтеся про своє здоров'я, адже туберкульоз - це одна з тих хвороб, які легше попередити, аніж потім тривалий час пікувати!

\section{ЛІТЕРАТУРА}

1. Протокол надання медичної допомоги хворим на туберкульоз : наказ Міністерства охорони здоров'я України від 28.01 .05 р. № 45.

2. Загальнодержавнацільова соціальнапрограма протидії захворюванню на туберкульоз на 2012-2016 рр.

3. Касевич Н. М. Загальний догляд за хворими і медична маніпуляційна техніка / Н. М. Касевич. - Київ : Медицина, 2008.

4. http://www.moz.gov.ua/ua/portal/ prof_tuberk.html

5. Савула М. М. Туберкульоз / М. М. Савула, О. Я. Ладний. - Тернопіль : Укрмедкнига, 1999.

6. Федищенко Ю.І. Сучасні методи діагностики, лікування і профрілактики туберкульозу / Ю.І.Федищенко, В. М. Мельник. - Київ : Здоров'я, 2002.

7. Пименчук М. С. Фтизіатрія / М. С. Пименчук, В. І. Петренко. - К. : Вища школа, 1998. 